\title{
Prospects for Improving the Marketing Policy of Huawei in the Context of the Trade War between the United States and China
}

\author{
Svetlana Staryh", Natalya Derkach, Svetlana Lavoshnikova, and Anastasia Chesnokova \\ South-West State University, Kursk, Russia
}

\begin{abstract}
The article examines the consequences of the trade war between the United States and China using the example of Apple and Huawei. Based on the calculation of the integral indicator, technical and economic parameters of the competitiveness of the products of these organizations were obtained. It was concluded that large-scale forms of competitive struggle are acquiring the character of a trade war, increasingly restraining the opponent with the help of the non-price factor of competition. In these conditions, the question of the prospects for further improving the marketing policy of Huawei is relevant.
\end{abstract}

In recent decades, the growth of China's economic power has been accompanied by a decline in the US share of global production and international trade. This led to a change in the geopolitical landscape of the world and the emergence of the" Group of Two Countries", or G2 for short [1]. The escalation of mutual claims initiated by the Trump administration, which began in 2017, resulted in a war of tariffs and sanctions, which in turn continues to have a very negative impact on relations between the two countries [2].

In this regard, the problem of transforming marketing policy by the protracted nature of the sanctions needs a practical justification. Recent achievements on the topic are devoted to the study of American-Chinese trade and economic relations at the turn of the presidency in the United States, consideration of digital marketing strategies of large technology companies. In this paper, we consider it necessary to analyze the competitiveness of smartphones and, based on the results obtained, consider the prospects for improving the marketing policy of Huawei.

The main purpose of this article is to study the marketing policy of Huawei in the context of the trade war between the United States and China.

The main tasks of the work are to analyze the competitiveness of smartphones from large manufacturers of both countries, to identify the potential for promoting Huawei products in the international market.

The last major criticism from the United States to China was an accusation of stealing hundreds of millions of dollars worth of American intellectual property. The consequences of this accusation were unilateral sanctions against the Chinese companies ZTE and

${ }^{*}$ Corresponding author: cvetlana.staryx.87@mail.ru 
Huawei, which significantly reduced their competitiveness and impeded the development of high-tech industries in China [3].

The administration of the new US President Joseph Biden has not yet taken decisive measures to eliminate the existing contradictions between the United States and China. At the same time, the media often speculates about the relaxation of trade conflicts after the revision of sanctions against Huawei, SMIC, and many other Chinese technology companies. As long as the sanctions against "Huawei" are not suspended, we will consider the topic of the trade war between the United States and China as relevant [4].

During 2015 - 2019 China's GDP was approximately 2 times lower than that of the United States. At the same time, China's GDP grew by an average of $7 \%$ per year, while the same indicator for the United States was only 4\% [5]. In 2018, China surpassed the United States in terms of GDP in terms of PPP in the following ratio: 25.2 trillion dollars from the PRC against 20.4 trillion dollars from the USA. At the same time, China's share in world GDP based on PPP increased from $2.3 \%$ in 1980 to about $18.3 \%$ in 2017 , while the share of the United States in world GDP based on PPP fell from 24.3\% to about $15.3 \%$ [6].

China's short-term economic superiority was impressive, especially given that in 1980 , China's PPP GDP was only one-tenth of that of the United States. The IMF predicts that by 2024, China's economy will be 56\% larger than the US economy based on PPP [6].

One of the central issues of the US economic relations with China for the US administration is the issue of the trade deficit. Despite tough measures from the United States to reduce the trade deficit with China, this figure has continued to rise in recent years [4]. The US trade balance with China at its peak in absolute terms in 2019 amounted to $48 \%$ of the US trade deficit (Table 1).

Table 1. Trade balance, billions of dollars

\begin{tabular}{|c|c|c|c|c|c|}
\hline & $\mathbf{2 0 1 5}$ & $\mathbf{2 0 1 6}$ & $\mathbf{2 0 1 7}$ & $\mathbf{2 0 1 8}$ & $\mathbf{2 0 1 9}$ \\
\hline $\begin{array}{c}\text { Trade balance of the } \\
\text { USA and China }\end{array}$ & $-367,33$ & $-346,83$ & $-375,17$ & $-418,95$ & $-345,20$ \\
\hline US trade balance & $-745,48$ & $-735,33$ & $-792,40$ & $-872,04$ & $-854,37$ \\
\hline China's trade balance & 678,7 & 610,6 & 489,2 & 382,4 & 429,6 \\
\hline
\end{tabular}

2019 was the third consecutive year of declines in global sales (second in the analyzed period), even with the emergence of a new 5G market and the supply of smartphones with new technologies, including foldable models (Table 2). 2019 proved to be successful for Samsung, Xiaomi, and OPPO. The company "Huawei" holds a leading position in terms of growth rate throughout the entire period under review. In 2018, Samsung and Apple recorded a $7.7 \%$ and $1.7 \%$ drop in smartphone sales, respectively, while Huawei posted a $30.1 \%$ increase.

In mid-June 2020, it became known that Huawei became the world's largest smartphone manufacturer for the first time and in April 2020 captured $21.4 \%$ of the global market [7]. Since the beginning of 2020, this Chinese company has increased its market share by $6 \%$. During this time, the share of Samsung increased by $2 \%$, and Apple decreased by $4 \%$. Let us analyze the competitiveness of the products of these two companies in the conditions of comparable comparability of Apple and Huawei in the current economic conditions [8]. 
Table 2. Global smartphone sales

\begin{tabular}{|c|c|c|c|c|c|c|c|c|}
\hline \multirow{2}{*}{} & \multicolumn{2}{|c|}{$\mathbf{2 0 1 9}$} & \multicolumn{2}{c|}{$\mathbf{2 0 1 8}$} & \multicolumn{2}{c|}{$\mathbf{2 0 1 7}$} & \multicolumn{2}{c|}{ Increment } \\
\cline { 2 - 9 } & $\begin{array}{c}\text { Sales, } \\
\text { mln. }\end{array}$ & $\begin{array}{c}\text { Market } \\
\text { share, } \\
\%\end{array}$ & $\begin{array}{c}\text { Sales, } \\
\text { mln. }\end{array}$ & $\begin{array}{c}\text { Market } \\
\text { share, } \\
\%\end{array}$ & $\begin{array}{c}\text { Sales, } \\
\text { mln. } \\
\text { share, } \\
\%\end{array}$ & $\begin{array}{c}2018- \\
2019\end{array}$ & $\begin{array}{c}2017- \\
2018\end{array}$ \\
\hline Samsung & 298,1 & 21,8 & 293,3 & 21,1 & 317,7 & 21,7 & $1,6 \%$ & $-7,7 \%$ \\
\hline Huawei & 240,6 & 17,6 & 206,0 & 14,8 & 154,2 & 10,5 & $16,8 \%$ & $33,6 \%$ \\
\hline Apple & 198,1 & 14,5 & 212,2 & 15,3 & 215,8 & 14,7 & $-6,6 \%$ & $-1,7 \%$ \\
\hline Xiaomi & 125,5 & 9,2 & 120,6 & 8,7 & 92,7 & 6,3 & $4,1 \%$ & $30,1 \%$ \\
\hline Oppo & 120,2 & 8,8 & 116,0 & 8,3 & 111,7 & 7,6 & $3,6 \%$ & $3,8 \%$ \\
\hline Others & 384,3 & 28,1 & 441,4 & 31,8 & 573,4 & 39,1 & $12,9 \%$ & $23,0 \%$ \\
\hline Total & 1366,8 & 100,0 & 1389,5 & 100,0 & 1465,5 & 100,0 & $-1,6 \%$ & $-5,2 \%$ \\
\hline
\end{tabular}

We will analyze the competitiveness of Apple and Huawei products using the example of smartphones in 2019 - iPhone 11 and Huawei P40. Since the leader in the field of smartphones is Samsung, the Samsung Galaxy S10 was taken as a sample, which, according to the ratings of several expert agencies, holds a leading position in the rating of smartphones in 2019 [9]. For the technical and economic indicators of comparison, the most important criteria were taken when choosing a smartphone. Expert assessments are the basis for determining the weight of each parameter in the general set.

Table 3. Technical and economic indicators of smartphones

\begin{tabular}{|l|c|c|c|c|}
\hline \multirow{2}{*}{ Indicators } & $\begin{array}{c}\text { Apple iPhone } \\
\mathbf{1 1}\end{array}$ & $\begin{array}{c}\text { Huawei } \\
\text { P40 }\end{array}$ & $\begin{array}{c}\text { Sample Samsung } \\
\text { Galaxy S10 }\end{array}$ & $\begin{array}{c}\text { Weight } \\
\text { coefficient }\end{array}$ \\
\cline { 2 - 5 } & $\mathrm{p} 1$ & $\mathrm{p} 2$ & $\mathrm{p} 0$ & $\mathrm{Ai}$ \\
\hline 1. Technical indicators & \multicolumn{5}{|l|}{} \\
\hline 1.1 Battery capacity, mAh & 3110 & 3800 & 3400 & 0,5 \\
\hline 1.2 Screen, inches & 6,1 & 6,1 & 6,1 & 0,2 \\
\hline 1.3 Camera (rear), MPix & 12 & 50 & 16 & 0,2 \\
\hline 1.4 Weight, g & 194 & 175 & 157 & 0,1 \\
\hline 2.Economic indicators & \multicolumn{5}{|c|}{} \\
\hline 2.1 Price, rub. & 54490 & 39999 & 53990 & 0,7 \\
\hline $\begin{array}{c}\text { 2.2 Smartphone processor } \\
\text { speed, MHz }\end{array}$ & 2650 & 2860 & 2840 & 0,3 \\
\hline
\end{tabular}

To distribute the models shown in Table 3 by the level of competitiveness, it is first necessary to calculate the simple indicators for technical and economic parameters relative to the basic model "Samsung" [10].

Let's define the group indicators of competitiveness: 
By technical parameter:

$$
\begin{aligned}
& G T 1=0.91 * 0.5+1 * 0.2+0.75 * 0.2+1.24 * 0.1=0.93 \\
& G T 2=1.12 * 0.5+1 * 0.2+3.13 * 0.2+1.11 * 0.1=1.5
\end{aligned}
$$

By economic parameter:

$$
\begin{aligned}
& G e 1=1.01 * 0.7+0.93 * 0.3=0.99 \\
& G e 2=0.74 * 0.7+1.01 * 0.3=0.82
\end{aligned}
$$

The resulting group indicator GTn characterizes the degree of compliance of a given product with the existing need for the entire set of technical parameters. Since the Huawei P40 has a higher figure, it generally satisfies the needs of consumers better than the iPhone 11. Calculations based on economic parameters show that the second model is more competitive, as it has the smallest group indicator equal to 0.82 .

Let's calculate the integral generall indicator of competitiveness (Table 4):

$$
\begin{aligned}
& I 1=G t 1 / G e 1=0.93 / 0.99=0.94 \\
& I 2=G t 2 / G e 2=1.5 / 0.82=1.83
\end{aligned}
$$

\begin{tabular}{|c|c|c|}
\hline Single indicators of competitiveness $(\mathrm{gi}=\mathrm{pi} / \mathrm{p} 0)$ & $\begin{array}{c}\text { Apple } \\
\text { iPhone } 11 \\
\text { (g1) }\end{array}$ & $\begin{array}{l}\text { Huawei } \\
\text { P40 (g2) }\end{array}$ \\
\hline \multicolumn{3}{|l|}{ 1. Technical indicators } \\
\hline 1.1 Battery capacity, mAh & 0,91 & 1,12 \\
\hline 1.2 Screen, inches & 1,00 & 1,00 \\
\hline 1.3 Camera (rear), MPix & 0,75 & 3,13 \\
\hline 1.4 Weight, $g$ & 1,24 & 1,11 \\
\hline \multicolumn{3}{|l|}{ 2.Economic indicators } \\
\hline 2.1 Price, rub. & 1,01 & 0,74 \\
\hline 2.2 Smartphone processor speed, $\mathrm{MHz}$ & 0,93 & 1,01 \\
\hline
\end{tabular}

Table 4. Calculation of single indicators

From the calculations of the integral indicator, it can be seen that the Huawei P40 smartphone is more competitive than the iPhone 11 since the value of this indicator is greater than 1.

Based on the conducted study, it can be concluded that today the company "Huawei" is a fairly efficiently functioning company. Despite serious sanctions restrictions, the foundation for the company's further sustainable development lies in the development of an effective digital marketing strategy.

The prospects for improving Huawei's marketing policy are as follows:

- the use of the ecosystem in the development and creation of new devices;

- transition to its software, the attraction of specialists for the manufacture of competitive analogs of American components;

- search for alternative ways to use Google services, such as the re-release of old versions of smartphones; 
- withdrawal of new products from sanctions by selling subsidiaries;

- developing a regulatory framework to provide access to their patents for $5 \mathrm{G}$ wireless communications [11].

Thus, we can conclude that in the first half of 2020, Huawei continued to increase its share of the smartphone market, develop new high-tech products, attracting buyers to the market of Chinese developers. The above calculation of the integral indicator of competitiveness considers only technical and economic parameters. At the same time, the presence of Google services in them is a significant aspect in the choice of modern models of smartphones based on Android OS. This nuance reduces the demand for Huawei smartphones, allowing competitors to take leading positions by taking advantage of nonprice competition. In turn, the United States, in the aggregate of all measures restraining the Chinese economy, uses this aspect to reduce the smartphone market share of a strong rival. Improved marketing policy should largely ease the sanctions, allowing the company to remain in the lead in the supply of smartphones.

The research paper is written as part of the state grant for 2021 (№0851-2020-0034).

\section{References}

1. W. M. Morrison, China's Economic Rise: History, Trends, Challenges, Implications for the United States, CRS, 38 (2019)

2. N. Y. Chetyrkina, Features of regulation of competitive relations, VFU, 2, 50-55 (2017)

3. V. B. Supyan, U.S.-China Trade and Economic Relations: Causes of Crisis and Its Prospects, RFEB, 9, 23-32 (2019)

4. L. Pan, The state and problems of China's foreign trade activities in the face of a trade war, RFEB, 11, 112-118 (2019)

5. H. Schweitzer, The New Competition Tool: Its institutional set-up and procedural design, Pub. Office of the EU, 52 (2020)

6. A. A. Ryazanov, Evolution of Competition Theory, Mos. Witte Un. 2, 21-29 (2017).

7. A. O. Bychkova, Analysis of the Competitiveness of Smartphones, Alley.science, 15, 425-428 (2017)

8. Counterpoint (2020) // https://www.counterpointresearch.com/global-smartphoneshare/

9. N. S. Kuchma, US - China trade war: reaction of stock exchanges to the transformation of the foreign policy agenda, RUDN J. of Economics, 3, 415-428 (2019)

10. M.D. Seditov, N.E. Shashkov, Methods for assessing the competitiveness of the company, AASR, 80-84 (2020).

11. F. Kayin, Exploring Huawei's Digital Marketing Strategy, N. Sc. 16-20 (2020) 